
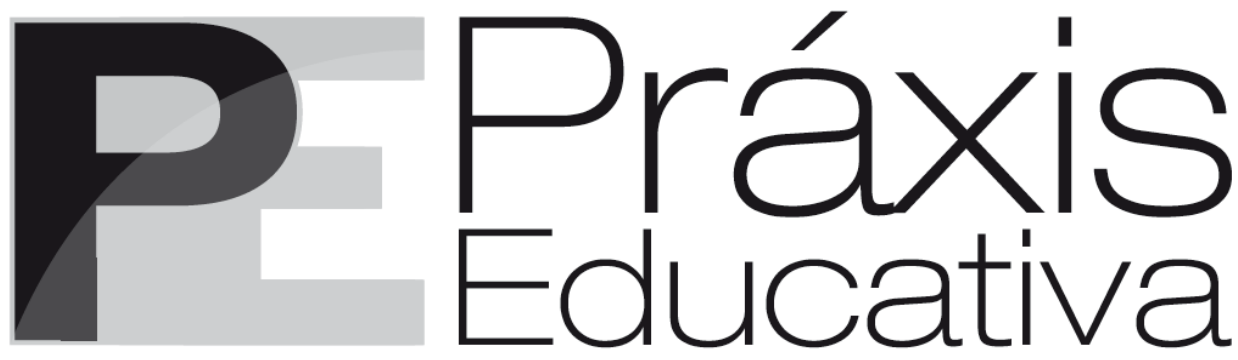

ISSN 1809-4031

elSSN 1809-4309

https://doi.org/10.5212/PraxEduc.v.15.14816.026

\title{
Educação Básica em "xeque”: Homeschooling e fundamentalismo religioso em tempos de neoconservadorismo
}

\section{Basic Education called into question: Homeschooling and Religious Fundamentalism in Neoconservatism times}

\section{Educación Básica en jaque: Homeschooling y fundamentalismo religioso en tiempos de neoconservadurismo}

\author{
Elcio Cecchetti ${ }^{*}$ \\ https://orcid.org/0000-0002-0946-320X \\ Anderson Luiz Tedesco ${ }^{* *}$ \\ (iD) https://orcid.org/0000-0002-7425-1748
}

\begin{abstract}
Resumo: Este trabalho objetiva compreender de que forma perspectivas religiosas fundamentalistas ameaçam o conceito de Educação Básica e, por conseguinte, colocam em xeque o ideal de escola pública, gratuita, obrigatória e laica, por meio da defesa e da regulamentação do homeschooling no Brasil. O estudo, de natureza qualitativa, do tipo bibliográfico e documental, é transversalizado por contribuições advindas dos campos epistemológicos das Ciências da Religião e da Educação, no intuito de evidenciar as estratégias ideológicas empreendidas por um ativismo religioso-fundamentalista e neoconservador contra temáticas relativas aos direitos sociais, direitos humanos e à laicidade escolar. A análise indica que o ensino domiciliar está enraizado em valores religiosos fundamentalistas, apoiado e fortalecido por partidos, instituições e líderes religiosos alinhados ao movimento neoconservador que se propaga na atualidade em escala internacional; e que uma possível regulamentação do ensino domiciliar colocará em xeque o direito público subjetivo à Educação Básica, direito assegurado após décadas de luta coletiva por uma escola gratuita, obrigatória, igualitária, inclusiva e laica.
\end{abstract}

Palavras-chave: Educação Básica. Homeschooling. Fundamentalismo religioso. Neoconservadorismo.

Abstract: This article aims to understand how fundamentalist religious perspectives threaten the concept of Basic Education and, therefore, call into question the ideal of free, compulsory and secular public school, through the defense and regulation of homeschooling in Brazil. The qualitative study of bibliographic and documentary type is transversalized by contributions coming from the epistemological fields of the Sciences of Religion and Education, in order to highlight the ideological strategies undertaken by a religious-

\footnotetext{
* Professor do Mestrado em Educação da Universidade Comunitária da Região de Chapecó (Unochapecó). Doutor em Educação pela Universidade Federal de Santa Catarina (UFSC). E-mail: <elcio.educ@hotmail.com>.

** Professor do Colégio La Salle de Xanxerê e Pesquisador em estágio Pós-doutoral na Universidade Comunitária de Chapecó (Unochapecó). Doutor em Filosofia pela Pontifícia Universidade Católica do Paraná (PUCPR). E-mail: <anderson.tedesco@unochapeco.edu.br>.
} 
fundamentalist and neoconservative activism against rights-related themes, social rights, human rights and school secularity. The analysis indicates that home-based education is rooted in fundamentalist religious values, supported and strengthened by political parties, institutions and religious leaders aligned with the neoconservative movement that is now spreading internationally; and that a possible regulation of homeschooling will jeopardize the subjective public right to Basic Education, this right is ensured after decades of collective struggle for a free, compulsory, equal, inclusive and secular school.

Keywords: Basic Education. Homeschooling. Religious fundamentalism. Neoconservatism.

Resumen: Este trabajo intenta comprender de qué forma perspectivas religiosas fundamentalistas amenazan el concepto de Educación Básica y, por consiguiente, colocan en jaque el ideal de escuela pública, gratuita, obligatoria y laica, por medio de la defensa y de la defensa y de la regulación del homeschooling en Brasil. El estudio, de carácter cualitativo, del tipo bibliográfico y documental, se transversaliza mediante contribuciones provenientes de los campos epistemológicos de las Ciencias de la Religión y de la Educación, con el fin de evidenciar las estrategias ideológicas emprendidas por un activismo religioso-fundamentalista y neoconservador contra temáticas relacionadas con los derechos sociales, derechos humanos y laicidad escolar. El análisis indica que el bomeschooling está enraizado en valores religiosos fundamentalistas, respaldado y fortalecido por partidos, instituciones y líderes religiosos alineados con el movimiento neoconservador que se propaga en la actualidad en escala internacional; y que una posible regulación del homeschooling pondrá en jaque el derecho público subjetivo a la Educación Básica, derecho asegurado después de décadas de lucha colectiva por una escuela gratuita, obligatoria, igualitaria, inclusiva y laica.

Palabras-clave: Educación Básica. Homeschooling. Fundamentalismo religioso. Neoconservadurismo.

\title{
Introdução
}

\begin{abstract}
Vossos filhos não são vossos filhos. São os filhos e as filhas da ânsia da vida por si mesma. Vêm através de vós, mas não de vós. E embora vivam convosco, não vos pertencem. Podeis outorgar-lhes vosso amor, mas não vossos pensamentos, porque eles têm seus próprios pensamentos. Podeis abrigar seus corpos, mas não suas almas; pois suas almas moram na mansão do amanhã, que vós não podeis visitar nem mesmo em sonho. Podeis esforçar-vos por ser como eles, mas não procureis fazê-los como vós, porque a vida não anda para trás e não se demora com os dias passados. Vós sois os arcos dos quais vossos filhos são arremessados como flechas vivas. $\mathrm{O}$ arqueiro mira o alvo na senda do infinito e vos estica com toda a sua força para que suas flechas se projetem, rápidas e para longe. Que vosso encurvamento na mão do arqueiro seja vossa alegria: pois assim como ele ama a flecha que voa, ama também o arco que permanece estável. (GIBRAN, 1981, p. 15).
\end{abstract}

A noção de "Educação Básica", tal como assinalou Cury (2002), é um conceito recente em nossa legislação educacional. Trata-se de uma conquista social, resultado de uma luta histórica, travada por inúmeros sujeitos, para que o acesso à educação elementar fosse considerado um direito fundamental às crianças, aos adolescentes, aos jovens e aos adultos, de forma gratuita, obrigatória e laica. O art. 205 da Constituição Federal de 1988 sedimentou que a educação é um direito de todos e dever do Estado e da família, a qual deve ser promovida em prol do pleno desenvolvimento do estudante, seu preparo para o exercício da cidadania e sua qualificação para o trabalho (BRASIL, 1988).

Por sua vez, a LDB No 9.394, de 29 de dezembro de 1996, estabeleceu que a Educação Básica é um nível da educação nacional que congrega, organicamente, três etapas: Educação Infantil, Ensino Fundamental e Ensino Médio. A ideia de desenvolvimento do educando, previsto pela Constituição, desdobra-se nessas etapas, cada qual direcionada a uma das fases da vida, cuja finalidade, conforme o art. 22, é assegurar a "formação comum indispensável para o exercício da cidadania" e fornecer os "meios para progredir no trabalho e em estudos posteriores" (BRASIL, 
1996, n.p.). Não por acaso, a Lei, em seu $\$ 1^{\circ}$, do art. $1^{\circ}$, explicita que tal educação se desenvolve, predominantemente, por meio do "ensino em instituições próprias" (BRASIL, 1996, n.p.).

Cury (2002), ao explorar o significado etimológico do termo "base", entendendo-o como "suporte, fundação e andar", indica que "educação básica" é "[...] um conceito mais do que inovador para um país que, por séculos, negou, de modo elitista e seletivo, a seus cidadãos o direito ao conhecimento pela ação sistemática da organização escolar" (CURY, 2002, p. 170). Assegurada na legislação como um "direito público subjetivo", a Educação Básica é um dever do Estado, que deve ofertá-la de forma obrigatória e gratuita na faixa etária dos 4 aos 17 anos de idade, inclusive àqueles que a ela não tiveram acesso em idade própria (BRASIL, 2009).

Assim, de um lado, temos o sujeito portador do direito à Educação Básica e, do outro, a obrigação estatal de oferecê-la. Em favor do primeiro, há um direito subjetivo; em relação ao segundo, há um dever jurídico a cumprir, de modo que, se comprovada a negligência da autoridade competente, esta poderá, de acordo com o $\$ 4^{\circ}$ do art. $5^{\circ}$, ser imputada por crime de responsabilidade (BRASIL, 1996).

De igual modo, é dever dos pais ou dos responsáveis efetuar a matrícula das crianças na Educação Básica a partir dos quatro anos de idade, como dispõe o art. $6^{\circ}$ da LDB e o art. 55 do Estatuto da Criança e do Adolescente (BRASIL, 1990). Os familiares que descumprirem tal preceito cometem o crime de "abandono intelectual", conforme prevê o Código Penal Brasileiro. Todavia, o fato de a Educação Básica constituir-se um direito público subjetivo - uma verdadeira conquista social após décadas de reivindicação - preocupa uma parcela minoritária da população, que almeja assegurar o direito de não enviar seus filhos à escola e educá-los em sua própria casa. São os defensores da homeschooling, expressão inglesa que remete à "educação no lar" ou "escolarização domiciliar ou doméstica".

Os adeptos a esse movimento inspiram-se na legislação educacional de países onde tal prática é permitida, tal como Estados Unidos, França e Austrália. Segundo Barbosa e Oliveira (2017, p. 15) o homeschooling é a opção de escolarização de mais de dois milhões de norte-americanos, que se opõem ao entendimento de que a "[...] educação compulsória se efetiva apenas sob a forma de educação escolar". Conforme indica Boto (2018), a opção pela educação domiciliar cresceu nos Estados Unidos mais de 100\% entre 1999 e 2010, e o contingente de crianças que atualmente são educados em casa é de aproximadamente 4\%. Segundo a autora, são as minorias religiosas as que mais aderem a essa modalidade de educação - elemento significativo que analisaremos na sequência.

No Brasil, onde a escolarização doméstica não possui previsão constitucional, diversas famílias entraram com processos judiciais requerendo o direito de educarem seus filhos em casa. Alguns casos tornaram-se mais emblemáticos, tal como o Mandado de Segurança No 7.407/2001, impetrado ao Superior Tribunal de Justiça (STJ) contra uma decisão do Conselho Nacional de Educação (CNE), que havia negado o direto de uma família goiana educar seus filhos em casa. O relator, ministro Peçanha Martins, ao também negar essa possibilidade, assim justificou sua decisão:

Os filhos não são dos pais, como pensam os Autores. São pessoas com direitos e deveres, cujas personalidades se devem forjar desde a adolescência em meio a iguais, no convívio social formador da cidadania. Aos pais cabem, sim, as obrigações de manter e educar os filhos, consoante a Constituição e as leis do País, asseguradoras do direito do menor à escola (art. $5^{\circ}$ e 53, I, da Lei n. 8.096/90) e impositivas de providências e sanções voltadas

\footnotetext{
${ }^{1}$ De acordo com Silveira (2009), o direito público subjetivo constituiu-se em um instrumento jurídico de controle da ação estatal, possibilitando ao cidadão, investido de seu direito, exigir judicialmente do Estado o cumprimento de seus deveres.
}

Práxis Educativa, Ponta Grossa, v. 15, e2014816, p. 1-17, 2020 Disponível em: <https://www.revistas2.uepg.br/index.php/praxiseducativa> 
à educação dos jovens como se observa no art. 129, e incisos, da Lei n. 8.096/90 supra transcritos, e art. 246, do Código Penal [...]. (BRASIL, 2005, p. 8).

Outro caso ilustrativo é o Recurso Extraordinário No 888.815 (BRASIL, 2018), decorrente de outro mandado de segurança impetrado por uma família gaúcha contra a Secretaria Municipal de Educação de Canela/RS, o qual tramitou em todas as instâncias até ser apreciado pelo Supremo Tribunal Federal (STF), em setembro de 2018. O caso já foi alvo de análise detalhada por parte de Alves Jr. (2018), mas consideramos de suma importância ressaltar alguns argumentos utilizados pela família durante o processo. Ao protocolar recurso contra a resposta da Secretaria da Educação, a defesa advogou que o "[...] convívio com alunos de várias idades não reflete um critério ideal de convivência e socialização, quer por aspectos sociais, quer por aspectos morais, quer por aspectos religiosos e até sexuais [...]" (BRASIL, 2018, p. 5). Ademais,

[...] por princípio religioso a Impetrante discorda de algumas imposições pedagógicas do ensino regular, como por exemplo, a questão atinente ao evolucionismo e à Teoria de Charles Darwin. Com efeito a Impetrante é Cristã (Criacionista) e não aceita viável ou crível que os homens tenham evoluído de um macaco, como insiste a Teoria Evolucionista. (BRASIL, 2018, p. 5).

Como se pode visualizar, justificações de cunho religioso estão a embasar os pedidos para oferta da educação domiciliar. Em última instância, está colocado novamente um conflito sobre a quem concorre a educação das novas gerações, atualizando um conflito histórico entre Igreja x Estado, público x privado, ensino confessional x ensino laico. Esse fenômeno se alastra como um "câncer", à medida que líderes religiosos de perspectiva fundamentalista vêm assumindo papéis importantes na política brasileira. Dentre eles, destaca-se a própria figura do Presidente da República, Jair Messias Bolsonaro, e a ministra da Mulher, dos Direitos Humanos e da Família, Damares Alves.

Logo após sua posse, no início de 2019, Bolsonaro anunciou que uma das medidas prioritárias no campo da educação para os seus cem primeiros dias de governo seria a regulamentação da homeschooling no Brasil. A promessa foi parcialmente cumprida com o envio à Câmara Federal do Projeto de Lei No 2.401/2019, que dispõe sobre o exercício do direito à educação domiciliar. Vale destacarmos que a principal porta-voz do Projeto foi a ministra Damares Alves, e não o ministro da Educação, ao qual o tema está diretamente vinculado (PICHONELLI, 2019).

Diante disso, neste trabalho, partimos da hipótese de que a bandeira da educação domiciliar no Brasil está enraizada em valores religiosos fundamentalistas, apoiada e fortalecida por partidos, instituições e líderes religiosos alinhados ao movimento neoconservador que se propaga na atualidade em escala internacional; e que uma possível regulamentação do ensino domiciliar colocará em xeque o direito público subjetivo à Educação Básica, direito assegurado após décadas de luta coletiva por uma escola gratuita, obrigatória, igualitária, inclusiva e laica.

Não por acaso, movimentos como o Escola sem Partido e contrários à "ideologia de gênero" também defendem o homeschooling como modelo ideal de educação, já que ambos se fundamentam no mesmo princípio, qual seja: de que a formação dada pela escola não deve interferir nos princípios e nos valores adotados pela família. Trata-se de um embate histórico, acerca de quem deve imprimir as finalidades sobre a educação dos menores: a Religião ou o Estado. Para os setores fundamentalistas e neoconservadores, a educação escolar não deve tratar de temas religiosos, políticos, sexuais e morais, e, caso insista em fazê-lo, a "solução" é educar os filhos em casa.

\footnotetext{
${ }^{2}$ Conferir Miguel (2016) e Santin, Cattani e Cecchetti (2019).
} 
Em vista disso, este trabalho objetiva compreender de que forma perspectivas religiosas fundamentalistas ameaçam o conceito de "educação básica" e, por conseguinte, colocam em "xeque" o ideal de escola pública, gratuita, obrigatória e laica, por meio da defesa e da regulamentação do bomeschooling no Brasil. O estudo, de natureza qualitativa, do tipo bibliográfico e documental, é transversalizado por contribuições advindas dos campos epistemológicos das Ciências da Religião e da Educação, no intuito de evidenciar as estratégias ideológicas empreendidas por um ativismo religioso-fundamentalista e neoconservador contra temáticas relativas aos direitos sociais, direitos humanos e à laicidade escolar.

Assim, em um primeiro momento, apresentamos um panorama histórico-conceitual dos embates entre o poder religioso e o poder civil no mundo ocidental, cujas bases posteriormente resultaram no ideal de laicidade estatal. Em um segundo momento, a partir de diferentes estudos e análises, precisamente do campo das Ciências da Religião, buscamos compreender as raízes do fundamentalismo religioso e sua adesão a movimentos neoconservadores para identificar porque defendem o homeschooling como alternativa de formação das "famílias de bem". Por fim, destacamos que a educação domiciliar traduz a ideia de que o Estado não possui autoridade moral sobre a educação dos menores, uma vez que não recebeu de Deus o poder para educar as novas gerações de cristãos. Ainda, segundo seus propositores, essa autoridade moral é exclusiva das famílias e da igreja, e não do Estado e das escolas e das universidades.

\section{Os embates históricos entre o poder religioso e o poder civil}

As disputas contemporâneas sobre quem detém o poder proeminente de educar os menores e sobre o tipo de formação a ser oferecida pela escola pública remetem aos embates históricos em torno da distinção e da separação entre o poder temporal e espiritual.

Desde uma perspectiva historiográfica, no mundo ocidental, foram os cristãos os primeiros a reivindicar a liberdade religiosa frente à opressão e à perseguição do Império Romano. Amparados por princípios teológicos, eles também se negavam a admitir a autoridade do imperador em matéria religiosa, pois Jesus havia ensinado que "meu Reino não é deste mundo" (BÍBLIA, 1990, p. 1382). Essa separação entre o poder terreno e divino, entre homens e Deus, entre este e outro mundo, representa uma concepção peculiar na história, não presente nos povos e nas culturas da época. Posteriormente, após o Cristianismo tornar-se religião oficial e selar sua aliança com o Império, a separação entre os poderes temporal e espiritual diluiu-se quando o próprio Estado se converteu em braço secular da Igreja. Entretanto, na condição de religião oficial do Estado, a Igreja ficou cada vez mais tutelada e viu-se obrigada a redefinir suas bases, estabelecendo princípios doutrinários totalmente distintos daqueles que a moveram nos primeiros séculos (CECCHETTI, 2016).

A dualidade dos dois "reinos" cedeu lugar, então, a uma teoria política desenvolvida nos 28 volumes da obra Cidade de Deus de Santo Agostinho (354-430 d.C.), que teve suas raízes no mundo grego, precisamente no platonismo. Nessa, a civitas dei e a civitas terrena encontram-se mescladas e confundidas até o dia do juízo final. A cidade terrestre representa a sociedade ímpia, governada pelo Estado pagão, enquanto a cidade divina é habitada pela comunidade das almas libertadas do pecado pela ação da Igreja. Por isso, Agostinho defende um Estado cristão que, além de gerir as "coisas do mundo", se ocupe em promover a verdadeira fé; enquanto a Igreja, na condição de provedora espiritual, zelaria pelos interesses divinos contando com o apoio do Estado (LABRIOLLE et al., 1975).

No pensamento agostiniano, o poder político deve, portanto, submeter-se ao poder religioso, cuja autoridade advém da esfera espiritual. A colaboração entre ambos não implicaria na 
perda da preeminência do poder espiritual, já que o governo civil estaria a serviço do reino celestial. A teoria da Cidade de Deus sustentará o pensamento político medieval até o início do século XI, subsidiando a relação, nem sempre amistosa, entre reis e papas.

Durante grande parte do medievo, apesar das alianças e plasmas históricos, o poder religioso e o poder temporal disputaram o summo potestas (poder soberano). Em dado período, a Igreja saiu vencedora e acumulou o poder político, científico e econômico; em outros, foram os príncipes que submeteram aos seus domínios o aparelho eclesiástico (BLACK, 1996).

A disputa pela supremacia das potestades, a decadência do regime feudal e a assunção de novas formas de organização política, em meio a guerras, imposições e perseguições, praticadas tanto pelo absolutismo dos monarcas quanto pela hierarquia da Igreja Católica, impulsionaram o nascimento de uma teoria política que apregoava a independência entre o império e o sacerdócio. O Estado laico, então, foi idealizado como estratégia mais eficaz para o governo da res pública (BAYONA-AZNAR, 2009).

A propagação de um modelo estatal cujo poder político autonomizou-se dos domínios religiosos foi acompanhado por um crescente movimento em favor das liberdades individuais dos cidadãos, para que todos fossem tratados indistintamente, independentemente de suas crenças e convicções. Tal tendência visava garantir a imparcialidade do Estado no tratamento de crentes ou não crentes, zelando pelo interesse público e pela coesão social. No entanto, foram necessários muitos séculos até o poder civil se estabelecer como independente da hierarquia eclesiástica. A Igreja por si mesma não admitiu abrir mão de seu domínio temporal, condenando quem ousava defender a origem laica do poder (BAYONA-AZNAR, 2007).

Com o Renascimento e a emergência dos Estados-nação, ocorreu a separação entre IgrejaEstado no continente europeu. Essa cisão resultou em dois modelos diferentes de governo: nos países protestantes do Norte, onde o monopólio da fé católica foi abalado pela Reforma Protestante, predominou o modelo "Igreja de Estado". Nesse contexto, o poder político absorveu as Igrejas Protestantes - como foi o caso do Anglicanismo e do Presbiterianismo na Inglaterra, e do Luteranismo na Dinamarca e na Noruega - e muitas das novas confissões foram perseguidas, o que motivou a imigração de puritanos, calvinistas, luteranos, quakers, entre outros, à Nova Inglaterra (América do Norte), durante os séculos XVI e XVII (MONOD, 2013).

No sul da Europa, ao contrário, a Igreja católica seguiu centralizando o poder político e "absorveu o Estado", regime transplantado às colônias católicas da América Latina e Caribe, onde por muito tempo perdurou a indissociável união entre Estado e Igreja, selada pelo regime do padroado. Por esse acordo, as Coroas católicas detinham o direito de administrar os assuntos religiosos em seus domínios ultramarinos, responsabilizando-se pelo financiamento e pelo controle da atividade missionária. Por isso, nessas colônias, o ideal de separação entre o político e o religioso ocorreu, na maioria das vezes, em meio a uma luta direta com a Igreja Católica que, de algum modo, conseguiu preservar certos privilégios e um significativo poder de influência social, mesmo após instaurado o processo de separação jurídica entre os poderes religioso e civil.

Já nas Treze Colônias da América do Norte, milhares de imigrantes protestantes que ali se estabeleceram levaram consigo o ideal da liberdade religiosa. Acreditavam que a América expressava a nova "terra prometida" por Deus, onde todos poderiam praticar e manifestar seu credo com a mais ampla liberdade. Assim, formaram uma sociedade extremamente religiosa, que se esforçava para cumprir os desígnios de Deus (KARNAL et al., 2007). Por conseguinte, tão logo as comunidades iam se instalando, escolas primárias foram criadas para que as crianças pudessem ler, escrever e interpretar a Bíblia (Sacras páginas). Assim, desde o início, as escolas não eram laicas, pois os fundamentos do Cristianismo orientaram, originalmente, o projeto educacional das colônias

Práxis Educativa, Ponta Grossa, v. 15, e2014816, p. 1-17, 2020 Disponível em: <https://www.revistas2.uepg.br/index.php/praxiseducativa> 
inglesas. Esses elementos históricos são úteis para que possamos compreender, na sequência, porque os Estados Unidos é a nação matriz dos movimentos fundamentalistas e neoconservadores que se expandiram por todo o continente.

Como é possível perceber, o processo de autonomização do poder político da esfera religiosa foi distinto e peculiar em cada contexto e, muito embora existam diferentes modelos, regimes e sentidos de laicidade, com base em Milot (2009), a entendemos como um princípio político-jurídico responsável por assegurar a "separação" entre o poder civil e o religioso; a "imparcialidade" do Estado frente às ideologias religiosas e seculares; e a "liberdade de consciência" e o "tratamento igualitário" dos cidadãos, salvaguardando o direito à diferença, à liberdade de crença, ao pensamento e à convicção.

Todavia, na atualidade, o crescimento do fundamentalismo religioso testa os limites e expõe as fragilidades dos regimes de laicidade em todas as partes. Não por acaso, muitos conflitos, revoltas armadas e lutas civis são decorrentes de desigualdades instituídas e discriminações produzidas por políticas que privilegiaram determina perspectiva particular, em detrimento do bem comum. "Um Estado que não é imparcial, que protege e promove somente uma crença religiosa, não pode cumprir com seu papel de árbitro das diferenças ou de articulador do interesse comum" (BLANCARTE, 2008, p. 54).

Isso exige que legisladores, dirigentes e funcionários públicos orientem seu trabalho para além da visão individual de mundo que compartilham, bem como saibam superar as pressões e os ditames dos grupos em disputa. Portanto, precisam resguardar o interesse público, mesmo que isso, às vezes, contrarie suas próprias convicções pessoais. Entretanto, no cenário político contemporâneo, em particular, no contexto brasileiro, percebemos cotidianamente que muitos legisladores e governantes buscam construir sua legitimidade política por meio de alianças com determinados setores religiosos, o que acaba por fragilizar sobremaneira o caráter laico do Estado. Nesse sentido, é cada vez mais visível a ação organizada de determinados segmentos religiosos com a finalidade de eleger seus representantes em todos os níveis do poder público, para que coloquem em pauta seus interesses particulares. Isso representa uma nítida apropriação da esfera pública (res publica) pelo mundo privado (res privata).

Por essas razões, é evidente que a defesa da laicidade é central para garantia das liberdades e dos direitos individuais e coletivos. Em sociedades de crescente diversificação sociocultural, onde situações de violações e injustiça proliferam por conta de processos de exclusão e desigualdades, a laicidade do Estado adquire um valor ainda maior. Encontrar mecanismos políticos, jurídicos e sociais que permitam ao Estado zelar pelo interesse público, ampliando o alcance dos direitos de todos, constitui sem dúvida, um grande desafio.

Em nossa concepção, a manutenção e o fortalecimento da laicidade estatal dependerá de um permanente investimento em processos educativos que capacitem todos os cidadãos a respeitarem os princípios de vida coletiva e a reconhecerem os direitos e as liberdades inerentes a todas as pessoas, independentemente de cultura, de etnia, de classe, de credo, de sexo, de gênero ou de condição social. Daí a importância capital da oferta da Educação Básica pública: assegurar a formação cidadã necessária à vida social, mediante a aprendizagem de conhecimentos científicos e de distintas visões de mundo, mesmo que isso desaponte familiares ou determinados grupos que desejam transmitir crenças ou convicções particulares.

Nessa perspectiva, as famílias não possuem o direito soberano seja para educar exclusivamente seus filhos em casa, seja para ditar às instituições escolares o que eles devem ou não aprender. Se essas interferências forem permitidas, coloca-se em perigo a realização de uma das finalidades mais importantes da Educação Básica: a aprendizagem da tolerância e da 
convivência entre os diferentes. Dada a necessidade de os estudantes interagirem e aprenderem a conviver com distintos perfis identitários, essa aprendizagem ficaria prejudicada se houvesse a liberação em função das crenças religiosas ou seculares de seus familiares. É nesse ponto (perigoso) que a regulamentação da escolarização domiciliar coloca em xeque as finalidades da Educação Básica.

Em outras palavras, a escola laica assume uma importância fundamental na promoção de sociabilidades que aprendam, acolham, colaborem e respeitem as diferenças. Daí decorre sua função social de contribuir na construção de uma cidadania que habilite as pessoas a conviverem com convicções de mundo distintas e a adotarem como legítimos alguns princípios básicos para vida coletiva, tais como a empatia, o respeito, a solidariedade e a liberdade. Até porque os princípios de convivialidade não são instituídos por decretos e nem exclusivamente construídos por valores familiares, mas fomentados por instituições, como as escolas e as universidades. $\mathrm{Na}$ medida em que os cidadãos passam a promovê-los em sua vida privada e pública, a sociedade ganha em estabilidade e coesão social.

Tudo isso fica prejudicado se o Estado e a escola sucumbirem aos interesses de movimentos fundamentalistas e neoconservadores que desejam impor seus princípios particulares como fundantes da ordem pública. Para isso, dentre outras estratégias, buscam assegurar no campo jurídico o "direito" das famílias promoverem uma educação personalizada e modelada segundo suas convicções religiosas, no "[...] intuito deliberado de escamotear a diversidade e a pluralidade que caracterizam tanto a sociedade quanto o próprio espaço escolar, sublevando, sobretudo, a diversidade e a liberdade de modos de ser, viver e pensar atinentes aos mais diversos sujeitos [...]" (SOUZA, 2019, p. 22). Assim sendo, o projeto de laicização do Estado e de suas instituições, resultado de um longo percurso histórico, está em xeque com o fortalecimento do fundamentalismo religioso e com a expansão do movimento neoconservador em escala intra e internacional.

\section{Neoconservadorismo e Fundamentalismo Religioso em defesa da educação domiciliar}

Nos últimos anos, diferentes estudiosos vêm buscando explicar a origem e as ações dos grupos neoconservadores no cenário brasileiro e internacional, tais como Apple (2013), Barroco (2011), Biroli (2018), Lacerda (2019), Lima e Hypolito (2019), Miguel (2016), Moll (2010), Penna $(2018,2019)$, entre outros. Em sua maioria, os estudos constatam a existência de conexões entre a agenda neoliberal, o ativismo neoconservador e o fundamentalismo religioso cristão. De acordo com Biroli (2019, p. 12), tal articulação tem colocado em "[...] xeque as balizas do sistema internacional de direitos humanos e da própria democracia como repertório institucional [...] para indivíduos e minorias sociais e políticas". Assim, não por acaso, pautas que incluem a defesa da família patriarcal e o combate à igualdade de gênero aparecem aliadas ao "[...] neoliberalismo, ao militarismo, ao punitivismo, ao anticomunismo e ao sionismo” (BIROLI, 2019, p. 13).

No Brasil, a defesa idílica da família tradicional como contraponto ao avanço da "ideologia de gênero", do "feminismo" e do "marxismo cultural", todos pretensamente chancelados e promovidos pelo Partido dos Trabalhadores (PT), criaram a atmosfera ideal para a assunção política dos grupos neoconservadores na esfera pública, culminando na eleição do presidente Bolsonaro e de dezenas de deputados estaduais e federais, governadores e senadores alinhados ao que Lacerda (2019) denomina de "novo conservadorismo brasileiro".

Em recente obra, Biroli (2018) defende a tese de que tal movimento é uma reelaboração do neoconservadorismo norte-americano, resultado de uma "coalizão" que reuniu grande parte do movimento religioso evangélico, parcela da direita secular do Partido Republicano e intelectuais de

Práxis Educativa, Ponta Grossa, v. 15, e2014816, p. 1-17, 2020 Disponível em: <https://www.revistas2.uepg.br/index.php/praxiseducativa> 
direita para eleger Ronald Reagan como presidente dos Estados Unidos em 1980. Diferentemente de outras articulações conservadoras, "[...] o eixo de gravidade do neoconservadorismo norteamericano - e do novo conservadorismo brasileiro - é a atuação da direita cristã baseada na ideia de que a família - e não o Estado - é a resposta para toda a ordem de disfunções sociais" (LACERDA, 2019, p. 18).

O neoconservadorismo, de acordo com Biroli (2018), pode ser entendido como um "movimento", um "modo de pensamento", um "conjunto de preferências" ou uma "força social" em busca de hegemonia no discurso público. Sua origem decorre de um agrupamento intelectual que se organizou no começo da Guerra Fria para construir um movimento baseado no "libertarismo econômico", no "tradicionalismo moral" e no "anticomunismo". O que uniu intelectuais tais como Leo Strauss e Irving Kristol foi o receio de que o Estado de bem-estar social, ao buscar diminuir as desigualdades, produziria um caos ao sistema capitalista vigente.

Com base em Huntington (1957), um dos pioneiros nos estudos sobre neoconservadorismo, Lacerda (2019) indica que a ideologia conservadora só surge quando forças sociais que desafiam a ordem estabelecida se tornam perigosas o suficiente para alterar o status quo. Essas ameaças seriam decorrentes das políticas de bem-estar social, como também dos movimentos LGBT e feministas, com suas pautas em favor da legalização do aborto, casamento homossexual, igualdade de gênero - todas entendidas como ameaças à família e aos valores cristãos.

Por sua vez, Apple (2013) nomeou os setores fundamentalistas de "populistas autoritários" porque suas posições decorrem da autoridade bíblica e da moralidade cristã, entendidas como fontes primordiais cujos currículos oficiais das escolas deveriam se pautar. Por isso, além de pressionar pela alteração dos livros didáticos, vigiar o trabalho dos professores e controlar os conteúdos ensinados, uma outra bandeira encampada é a educação dos filhos em casa, já que a interferência do Estado na vida da família representa um perigo. Trata-se de um "projeto educacional reacionário", tal como definido por Cunha (2016), no qual

[...] o currículo da Educação Básica, particularmente das escolas públicas, é objeto de ação modeladora que visa frear os processos de secularização da cultura e de laicidade do Estado, mediante dois movimentos, um de contenção, outro de imposição. Ambos os movimentos configuram um projeto de educação reacionária, entendida aqui como a que se opõe às mudanças sociais em curso e se esforça para restabelecer situações ultrapassadas. (CUNHA, 2016, p. 2-3).

Desse modo, o bomeschooling é uma resposta tanto ao "perigo" advindo da diversidade, já que os estudantes na escola são obrigados a conviver com os diferentes, quanto a ideia de que os responsáveis pela educação das novas gerações são os pais, já que o Estado - logo as escolas - não devem educar, mas, sim, apenas ensinar conteúdos.

Como é possível verificar, o fundamentalismo religioso cristão é a espinha dorsal desta coalizão neoconservadora, por isso é fundamental o aprofundamento da questão. Antes de tudo, é importante considerarmos que as religiões fazem parte da cultura humana e estão presentes desde tempos imemoriais. Nas sociedades tradicionais do passado e do presente, as religiões representam uma força muito poderosa na organização da vida social. Elas se distinguem de outras esferas sociais, exercendo funções específicas: procuram satisfazer angustias e necessidades individuais, proporcionando conforto e proteção diante do caos; apresentam explicações sobre as origens da vida e da morte; embasam leis, normas e costumes; e atuam em favor da coesão dos indivíduos e da perpetuação das visões de mundo desenvolvidas por determinada coletividade. De acordo com Eaton (2009): 
Educação Básica em "xeque": Homeschooling e fundamentalismo religioso...

As religiöes são amplas e profundas. Cada uma tem um ponto de origem, ensinamentos e textos, dogmas, crenças e rituais, ética e declarações de verdade universal. Num nivel mais profundo, as religiöes começam e terminam em mistério. Elas tratam de experiências de uma dimensão inefável da vida: o sentido misterioso, vivo, arrebatador e, ainda assim, incontestável do milagre da vida. (EATON, 2009, p. 112).

Contudo, as religiões, assim como as demais esferas sociais, atuam de modo ambivalente, apresentando doutrinas e práticas contraditórias que podem provocar tanto a opressão quanto a libertação, tanto a guerra quanto a paz. Influenciadas por intencionalidades políticas, sociais, econômicas, entre outras, os discursos religiosos podem instaurar práticas excludentes e discriminatórias. Daí podemos concluir que muitas coisas positivas derivaram da religião, mas muitas negativas também.

Com o advento da ciência moderna, em certo momento, acreditou-se que as religiões estavam fadadas a desaparecer. Todavia, como explica Eller (2018), as religiões sobreviveram às "investidas" da modernização e da laicização, revelando sua capacidade de adaptar-se às influências externas e absorvê-las. "Não só a religião não desapareceu silenciosamente, mas vicejou e multiplicou-se, produzindo mais religiões e novos movimentos religiosos [...] do que os estudiosos podiam acompanhar" (2018, p. 432). Ademais, grande parte desses movimentos religiosos ofereceram "resistência" à modernização, à diversificação cultural e a outras religiões.

É nesse contexto que precisamos situar o fundamentalismo. Ele não é uma religião em si, nem uma denominação religiosa; é apenas um dos jeitos possíveis de viver a religião. Ele não é fenômeno exclusivo da religião, pois há posturas fundamentalistas na política, na economia e até no futebol. Dessa maneira, assim como existem múltiplas religiosidades, podemos deduzir que há muitos fundamentalismos, nem todos ativistas, militantes, conservadores ou violentos.

Como explicita Eller (2018), o fundamentalismo religioso deriva seu nome da noção de "fundamentos", termo que remete aos elementos tidos como essenciais e centrais de qualquer crença ou doutrina, aquilo que "constituiu a cosmovisão e a verdade para os praticantes" (ELLER, 2018, p. 434, grifo do autor). No caso do Cristianismo, esses fundamentos em geral são:

[...] a Bíblia enquanto documento literal e infalivel e fonte de conbecimento; a exclusão e às vezes a condenação dos outros (até outros cristãos) como corruptos e perdidos; uma nítida distinção entre a religião e o 'secular', sendo este último inferior ou até mesmo mal; uma escatologia no qual o fim dos tempos está próximo e somente eles sobreviverão para entrar no novo reino; uma moralidade intransigente; e, cada vez. mais, uma disposição de participar da política para institucionalizar tudo o que foi arrolado acima, inclusive um desejo mais ou menos consciente de desmantelar a separação entre Igreja e Estado. (ELLER, 2018, p. 434).

Os primeiros a utilizar o termo "fundamentalistas", de acordo com Armstrong (2009), foram protestantes americanos que, no início do século XX, assim passaram a se autodenominar para diferenciarem-se de protestantes mais "liberais" que, a seu modo de ver, distorciam os princípios da vida cristã. Desejavam voltar às raízes e recuperar o essencial da tradição cristã, por meio da leitura e da interpretação literal da Bíblia. Inicialmente, essas expressões do fundamentalismo cristão deram origem a movimentos diversos naquele país, alguns bastante radicais, como os Amish, que não só rejeitam o mundo moderno, mas separaram-se fisicamente dele.

Eller (2018) acrescenta que um dos marcos do fundamentalismo cristão foram os doze volumes dos The fundamentals: a testimony to the truth (Os fundamentos: um testemunho da verdade), publicados entre 1910 e 1915. Desse trabalho surgiu uma organização, a Associação Mundial de Fundamentos Cristãos, fundada por Wiliam B. Riley, em 1919, disposta a "travar uma batalha decisiva" pelos fundamentos cristãos. Posteriormente, vários movimentos dessa natureza foram surgindo, mas cada um se considerava o representante autêntico do Cristianismo.

Práxis Educativa, Ponta Grossa, v. 15, e2014816, p. 1-17, 2020 Disponível em: <https://www.revistas2.uepg.br/index.php/praxiseducativa> 
O ponto alto do fundamentalismo cristão americano, segundo Eller (2018), deu-se com o caso conhecido como "julgamento do macaco", ocorrido no Tennessee, em 1925, no qual o professor John Thomas Scopes foi acusado pelo crime de ensinar a evolução. Mais tarde, foi o fortalecimento do movimento em prol dos direitos civis, na década de 1950, que desesperou alguns fundamentalistas, que organizaram atividades anti-imigração, como a Ku Klux Klan (anterior, um corolário da derrota sulista na Guerra Civil). Entretanto, somente a partir dos anos de 1960 e 1970, que o movimento fundamentalista estadunidense assumiu um novo papel no espaço público.

Com o crescimento dos movimentos feministas, hippies, gays e ateístas, supostamente "pisoteando" os valores tradicionais e as definições convencionais de família, religiosos fundamentalistas de diferentes denominações deixaram de lado suas diferenças teológicas e começaram a compor alianças para garantir que suas agendas passassem a incidir sobre a esfera pública. A gota d'água foi a decisão da Suprema Corte, em 1973, que legalizou o aborto. Para alguns, isso equivalia ao "assassinato legalizado" e ao "satanismo de Estado". A partir dessa data, bastaram poucos anos para o fundamentalismo se cristalizar na sociedade estadunidense (ELLER, 2018).

Desde então, a relação entre os fundamentalismos e o Estado é problemática. Alguns grupos são hostis a qualquer Estado, pois Deus ou a religião é a única fonte da autoridade e da lei. Outros são pró-Estado, pois veem os governos como meio estratégico para instaurar a ordem divina sobre o mundo. Disso advém ingredientes perigosos, pois, para estabelecer tal ordem, os fundamentalismos agem de maneira antidemocrática, antipluralista e anti direitos humanos. Essa atitude, como explica Eller (2018),

[...] decorre da autoridade sobre-humana do sistema: o poder e a soberania não são funções do demos, mas do divino. Da mesma forma, naturalmente, todas as outras posições, mesmo oposições leais, estão necessária e completamente erradas. Assim, a legitimação do movimento e suas resultantes instituições e regime acarretam quase inevitavelmente a deslegitimação de todas as alternativas e rivais possíveis, que são punidos como maus, corruptos e assim por diante. (ELLER, 2018, p. 441).

Tal compreensão é absolutista e unilateral, gerando desprezo às outras formas de viver e de compreender a realidade, pois parte do pressuposto de que há uma única verdade, a que está sob sua posse, recorrendo, inclusive, a práticas violentas sempre que necessário. Nessa perspectiva, não há possibilidade de diálogo, apenas de imposição da "verdade" aos demais, já que verdades devem ser aceitas e não debatidas, pois estão na Bíblia e ela não contém erros. "Tudo que está na Bíblia foi inspirado por Deus e, portanto, deve ser acatado, pois é para o bem e felicidade do ser humano. Se o que está escrito na Bíblia foi inspirado por Deus, qualquer interpretação da mente humana é, para os fundamentalistas, ofensiva a Deus" (PANASIEWICZ, 2008, p. 6).

$\mathrm{Na}$ óptica dos fundamentalistas cristãos, sobretudo norte-americanos, a "América" começou como uma nação fundada nos princípios bíblicos, porém, com o passar do tempo, teria se afastado de Deus, chegando até a permitir o aborto e a permissividade sexual. Por isso, chegou a hora dos valores republicanos saírem de cena e, em seu lugar, ser instaurada a "Nação Cristã" projeto que é uma verdadeira afronta a laicidade estatal!

No contexto brasileiro, o anseio de instaurar uma nação cristã revela-se em discursos recorrentes, tais como: "Deus acima de tudo" (slogan da campanha presidencial de Jair Bolsonaro); "É o momento de a igreja governar" (ministra Damares Alves3); "vamos ganhar o Brasil pra Jesus"

\footnotetext{
3 Conferir em: <https://www.metro1.com.br/noticias/politica/65395,e-o-momento-de-a-igreja-governar-declarafutura-ministra-de-bolsonaro>. Acesso em: $30 \mathrm{dez} .2019$.
}

Práxis Educativa, Ponta Grossa, v. 15, e2014816, p. 1-17, 2020 Disponível em: <https://www.revistas2.uepg.br/index.php/praxiseducativa> 
(Bispa Sonia Hernandes ${ }^{4}$ ); “a Bíblia e a Constituição deve[m] nos guiar” (Discurso de Bolsonaro após vitória eleitoral em 20185); ainda, "vamos indicar ministro 'terrivelmente evangélico' para o STF (Presidente Bolsonaro $\left.{ }^{6}\right)^{7}$

Se isso não bastasse, desde agosto de 2019, tais proposições estão instruídas por uma “assessoria externa” enviada pelo Governo Trump. Trata-se do Capitol Ministries, organização evangélica que ensina às mais altas autoridades dos governos a usar a Bíblia para orientar e justificar as políticas públicas. O pastor Raul José Ferreira Jr., responsável por conduzir os estudos bíblicos no Senado, afirmou que: "Nosso objetivo é reconstruir a nação a partir de valores cristãos que são forjados através do estudo da palavra"

Nesse terrível cenário, tanto a Educação Básica quanto o Ensino Superior estão em xeque: de um lado, grupos empresariais intentam abocanhar os recursos públicos do Estado mediante a defesa do regime de terceirização e/ou vouchers (FREITAS, 2018); de outro, ataques constantes ao papel da ciência, à validez do conhecimento científico - sobretudo os decorrentes das ciências humanas - à liberdade de cátedra, à autonomia da escola e à função pública da Educação Básica. Contudo, por que a educação? Por que a Educação Básica se tornou alvo dos movimentos fundamentalistas?

\section{Considerações finais: a Educação Básica como campo de disputa religiosa}

Com laicização do Estado, a escola deixou de ser uma instituição eclesiástica que estava a serviço da transmissão de valores morais religiosos, como era no período em que prevalecia o acordo entre Estado e Igreja. Nesse sentido, a função social da instituição escolar é de assegurar a formação comum indispensável para o exercício da cidadania, por meio de currículos que mobilizem conhecimentos científicos e desenvolvam atitudes e valores necessários à vida coletiva. Segundo Vasconcelos e Boto (2020):

A escola tem três funçôes na vida das crianças: a primeira delas - e certamente a mais importante - é a de se colocar como instância intermediária entre a família e a vida social. É como se a escola preparasse a criança para o seu ingresso no mundo público. Essa é sua primeira função. As outras duas são decorrentes dessa. Em nossa sociedade, o acesso à cultura letrada é um requisito. E a escola é a instituição voltada a ensinar a criança a lidar com os códigos da cultura escrita - essa é a segunda função da escola. E, finalmente, a terceira função é a de um aprendizado de valores e de códigos de comportamento considerados adequados e condizentes com o que a sociedade entende ser importante. A escola, então, supõe um aprendizado da ética e da civilidade. (V ASCONCELOS; BOTO, 2020, p. 15).

Contudo, na óptica dos fundamentalistas religiosos, tais funções sociais da escola desvirtuam, contaminam e dificultam os menores a seguirem os valores morais da religião. Por isso, a proposta do homeschooling de resguardar os filhos do "mundo profano" para educá-los no "mundo sagrado" do lar contradiz e desafia as funções da escola apresentado por Vasconcelos e Boto (2020).

Em suma, os próprios princípios que direcionam o ensino previstos em nossa Carta Magna, no art. 206 - liberdade de aprender, ensinar, pesquisar e divulgar o pensamento, a arte e o saber; e pluralismo de ideias e de concepções pedagógicas (BRASIL, 1988) - estão ameaçados diante das

\footnotetext{
${ }^{4}$ Disponível em: <http://www.bispasoniaoficial.com.br/noticias2.php?id=80>. Acesso em: 30 dez. 2019.

5 Disponível em: <https://noticias.r7.com/eleicoes-2018/bolsonaro-diz-que-vai-governar-o-brasil-com-a-biblia-e-aconstituicao-29102018>. Acesso em: 30 dez. 2019.

6 Conferir em: <https://g1.globo.com/politica/noticia/2019/07/10/bolsonaro-diz-que-vai-indicar-ministroterrivelmente-evangelico-para-o-stf.ghtml>. Acesso em: 30 dez. 2019.

${ }^{7}$ Para aprofundar o avanço do fundamentalismo religioso na política brasileira, conferir Burity (2018).

8 Disponível em: <https://apublica.org/2019/08/os-pastores-de-trump-chegam-a-brasilia-de-bolsonaro/\#Link1>. Acesso em: 30 dez. 2019.
} 
disputas acirradas protagonizadas por grupos fundamentalistas que pretendem gerir a Educação Básica segundo suas próprias visões de mundo. Tanto no Brasil como nos Estados Unidos, tais grupos buscam impregnar e recolonizar as instituições estatais, sobretudo a escola, dada a sua importância sobre a formação das identidades das novas gerações. Movimentos como o Escola sem Partido, contrários à "ideologia de gênero" e a favor da militarização do ensino", constituem, em solo brasileiro, as principais armas de ataque. No entanto, caso não consigam controlar as escolas públicas, a alternativa será fundar escolas privadas confessionais, escolas miliares e assegurar o direito ao homeschooling, onde estes possam ensinar seus próprios currículos. Para Souza (2019), essas táticas constituem estratégias de longo prazo visando a transformação social no que os fundamentalistas cristãos entendem ser o alicerce da sociedade: “[...] uma educação dita cristã já desde os níveis mais fundamentais do processo educativo, como sendo a forma mais eficaz de garantir que a moral cristã permeie futuramente todas as instituições da vida secular" (SOUZA, 2019, p. 24), segundo o objetivo de construir uma Nação Cristã.

Daí advém o argumento principal que embasa o homeschooling: a ideia de que o Estado não possui autoridade moral sobre a educação dos menores, uma vez que não recebeu de Deus o poder para educar as novas gerações de cristãos. Para seus propositores, essa autoridade moral é exclusiva das famílias e da igreja, e não do Estado e das escolas. No debate acerca do Projeto de Lei que regulamenta o ensino domiciliar no Brasil, realizado em 15 de outubro de 2019, na Comissão de Direitos Humanos e Legislação Participativa do Senado Federal, a representante do Ministério da Mulher, Família e dos Direitos Humanos, Ângela Martins, disse que o bomeschooling devolve aos pais o "controle" sobre a educação dos filhos: "Nós vemos infelizmente uma omissão, uma delegação para a escola de o que seria, em primeiro lugar, uma tarefa familiar. Se lava as mãos e a escola educa. O que nós queremos é essa reflexão da prioridade dos pais na educação dos filhos". ${ }^{10}$

Como denúncia, segundo Apple (2013), para alcançar seus objetivos, grupos fundamentalistas projetam discursivamente a si mesmos como "novos oprimidos", como pessoas cujas identidades e culturas são ignoradas ou atacadas nas escolas. Eles difundem que há um sério perigo quando o Estado se intromete na vida da família. Argumentando que a escola convencional é muito problemática, seus defensores - no Brasil representados pela Associação Nacional de Educação Domiciliar (ANED) ${ }^{11}$ - contam histórias de "horror" do ensino público e difundem exemplos de sucesso do ensino domiciliar.

Diante dos elementos apresentados, entendemos que nossa hipótese inicial está confirmada: a defesa da educação domiciliar no Brasil está enraizada em valores religiosos fundamentalistas, apoiada e fortalecida por partidos, instituições e líderes religiosos alinhados ao movimento neoconservador que se propaga na atualidade em escala internacional; e que uma possível regulamentação do ensino domiciliar colocará em xeque o direito público subjetivo à Educação Básica, direito este assegurado após décadas de luta coletiva por uma escola gratuita, obrigatória, igualitária, inclusiva e laica.

Por conseguinte, o debate sobre a quem compete a educação das futuras gerações segue tensionado: de um lado, o Estado laico, com seu dever de fornecer os instrumentos básicos para formação cidadã e preparação dos estudantes para estudos posteriores e para o mundo do trabalho; de outro, crescentes grupos político-religiosos entendem que a responsabilidade de educar as crianças é exclusiva da alçada das famílias.

\footnotetext{
${ }^{9}$ Sobre o tema da militarização do ensino, consultar: Lacé, Santos e Nogueira (2019) e Martins (2019).

${ }^{10}$ Disponível em: <https://noticias.r7.com/educacao/regulamentacao-do-ensino-domiciliar-e-defendida-no-senado15102019?amp>. Acesso em: 30 dez. 2019.

${ }^{11}$ Saiba mais em <https://www.aned.org.br/>. Acesso em: 30 dez. 2019.
}

Práxis Educativa, Ponta Grossa, v. 15, e2014816, p. 1-17, 2020 Disponível em: < https://www.revistas2.uepg.br/index.php/praxiseducativa> 
Nesse cenário, a escola e as universidades públicas, instituições centrais da vida moderna, encontram-se situadas em um campo de batalha ideológico, porque é por meio delas que a ordem social mais ampla é reproduzida, uma vez que o conjunto de experiências escolares e universitárias são decisivas na socialização das gerações jovens à cultura pública do Estado-Nação. Por isso, conclui-se que o homeschooling é mais um dos nefastos tentáculos que o projeto moralizador de cunho fundamentalista religioso e neoconservador de colocar em "xeque" o funcionamento das instituições formativas estatais, fragilizando e afrontando o direito público subjetivo à Educação Básica.

\section{Referências}

ALVES JUNIOR, L. C. M. A educação domiciliar (homeschooling) no banco dos réus: uma breve análise do processo e do julgamento do recurso extraordinário $n^{\circ} 888.815$, sob as luzes do direito humano fundamental da criança à educação. Revista Científica de Direitos Humanos, Brasília, v. 1, n. 1, p. 35-57, nov. 2018.

APPLE, M. W. Fazendo o trabalho de Deus: ensino domiciliar e trabalho de gênero. In: APPLE, M. W.; BALL, S. J.; GANDIN, L. A. (Orgs.). Sociologia da educação: análise internacional. Porto Alegre: Penso, 2013. p. 166-176.

ARMSTRONG, K. Em nome de Deus: o fundamentalismo no judaísmo, no cristianismo e no islamismo. São Paulo: Companhia das Letras, 2009.

BARBOSA, L. M. R.; OLIVEIRA, R. L. P. de. Apresentação do dossiê: homeschooling e o direito à educação. Pro-Posições, Campinas, v. 28, n. 2, p. 15-20, maio/ago. 2017. DOI: https://doi.org/10.1590/1980-6248-2017-0121

BARROCO, M. L. S. Barbárie e neoconservadorismo: os desafios do projeto ético-político. Serviço Social \& Sociedade, São Paulo, n. 106, p. 205-218, abr./jun. 2011. DOI: https://doi.org/10.1590/s0101-66282011000200002

BAYONA-AZNAR, B. Religión y poder: Marsilio de Padua: ¿la primera teoría laica del Estado? Madrid: Biblioteca Nueva, 2007.

BAYONA-AZNAR, B. El origen del estado laico desde la Edad Media. Madrid: Tecnos, 2009.

BÍBLIA. Livro de João. In: BÍBLIA sagrada. Português. Edição pastoral. Tradução Ivo Storniolo e Euclides Martins Balancin. São Paulo: Paulus, 1990. p. 1352-1387.

BIROLI, F. Reação conservadora, democracia e conhecimento. Revista de Antropologia, São Paulo, v. 61, n. 1, p. 83-94, 2018. DOI: https://doi.org/10.11606/2179-0892.ra.2018.145515

BLACK, A. El pensamiento político en Europa, 1250-1450. Cambridge: Cambridge University Press, 1996.

BLANCARTE, R. J. Para entender el estado laico. México: Nostra Ediciones, 2008. 
BOTO, C. “Homeschooling”: a prática de educar em casa. Jornal USP, São Paulo, 2018. Disponível em: <https://jornal.usp.br/artigos/homeschooling-a-pratica-de-educar-em-casa/>. Acesso em: 30 dez. 2019.

BRASIL. Decreto $\mathbf{N}^{\circ}$ 2.848, de 7 de dezembro de 1940. Código Penal. Brasília: Presidência da República, Casa Civil, Subchefia para Assuntos Jurídicos, [1940]. Disponível em: <http://www.planalto.gov.br/ccivil_03/decreto-lei/del2848compilado.htm>. Acesso em: 30 dez. 2019.

BRASIL. [Constituição (1988)]. Constituição da República Federativa do Brasil. Brasília, DF: Senado, 1988.

BRASIL. Lei $\mathrm{N}^{o}$ 8.069, de 13 de julho de 1990. Dispõe sobre o Estatuto da Criança e do Adolescente e dá outras providências. Diário Oficial da União: seção 1, Brasília, DF, n. 135, p. 13563, 16 jul. 1990.

BRASIL. Lei $\mathbf{N}^{\circ}$ 9.394, de 20 de dezembro de 1996. Estabelece as diretrizes e bases da educação nacional. Brasília: Presidência da República, Casa Civil, Subchefia para Assuntos Jurídicos, [1996]. Disponível em: <http://www.planalto.gov.br/ccivil_03/leis/19394.htm>. Acesso em: 30 dez. 2019.

BRASIL. Superior Tribunal de Justiça. Primeira Seção. Mandado de Segurança n. 7.407. Ensino Fundamental. Currículo ministrado pelos pais independente da frequência à escola. Impossibilidade. Ausência de direito líquido e certo. Ilegalidade e/ou abusividade do ato impugnado. Inocorrência. Lei 1.533/51, art. $1^{\circ}$, cf, arts. 205 e 208, \ $3^{\circ}$; lei 9.394/60, art. 24, vi e lei 8.096/90, arts. $5^{\circ}$, 53 e 129. Relator ministro Francisco Peçanha Martins. Julgamento em 24 abr. 2002. Acórdão publicado em 21 mar. 2005. Disponível em: <https://stj.jusbrasil.com.br/jurisprudencia/121865/mandado-de-seguranca-ms-7407-df-20010022843-7>. Acesso em: 30 dez. 2019.

BRASIL. Emenda Constitucional No 59, de 11 de novembro de 2009. Acrescenta $\int 3^{\circ}$ ao art. 76 do Ato das Disposições Constitucionais Transitórias para reduzir, anualmente, a partir do exercício de 2009, o percentual da Desvinculação das Receitas da União incidente sobre os recursos destinados à manutenção e desenvolvimento do ensino de que trata $\mathrm{O}$ art. 212 da Constituição Federal, dá nova redação aos incisos I e VII do art. 208, de forma a prever a obrigatoriedade do ensino de quatro a dezessete anos e ampliar a abrangência dos programas suplementares para todas as etapas da educação básica, e dá nova redação ao $\int 4^{\circ}$ do art. 211 e ao $\int 3^{\circ}$ do art. 212 e ao caput do art. 214, com a inserção neste dispositivo de inciso VI. Diário Oficial da União: seção 1, Brasília, DF, n’ 216, p. 8, 12 nov. 2009.

BRASIL. Projeto de Lei $\mathbf{N}^{\mathrm{o}}$ 2.401, de 17 de abril de 2019. Dispõe sobre o exercício do direito à educação domiciliar, altera a Lei no 8.069, de 13 de julho de 1990 - Estatuto da Criança e do Adolescente, e a Lei $\mathrm{n}^{\circ}$ 9.394, de 20 de dezembro de 1996, que estabelece as diretrizes e bases da educação nacional. Brasília: Câmara dos Deputados, [2019]. Disponível em: <https:/ /www.camara.leg.br/proposicoesWeb/fichadetramitacao?idProposicao=2198615>. Acesso em: 30 dez. 2019.

BRASIL. Supremo Tribunal Federal. Recurso extraordinário com agravo n. 778141. 2018. Disponível 
Educação Básica em "xeque": Homeschooling e fundamentalismo religioso...

<http://redir.stf.jus.br/estfvisualizadorpub/jsp/consultarprocessoeletronico/ConsultarProcesso Eletronico.jsf?seqobjetoincidente $=4774632>$. Acesso em: 30 dez. 2019.

BURITY, J. A onda conservadora na política brasileira traz o fundamentalismo ao poder? In: ALMEIDA, R. de; TONIOL, R. Conservadorismos, fascismos e fundamentalismos: análises conjunturais. Campinas: Editora Unicamp, 2018, p. 15-65.

CECCHETTI, E. A laicização do ensino no Brasil (1889-1934). 2016. 322 f. Tese (Doutorado em Educação) - Universidade Federal de Santa Catarina, Florianópolis, 2016.

CUNHA, L. A. $\mathbf{O}$ projeto reacionário na educação. Disponível em: $<$ http://luizantoniocunha.pro.br/uploads/independente/1-EduReacionaria.pdf>. Acesso em: 30 dez. 2019.

CURY, C. R. J. A Educação Básica no Brasil. Educação \& Sociedade, Campinas, v. 23, n. 80, p. 168-200, set./2002. DOI: https://doi.org/10.1590/s0101-73302002008000010

EATON, H. Honrar a criança e a religião: questões e insights. In: CAVOUKIAN, R.; OLFMAN, S. (orgs.). Honrar a criança: como transformar este mundo. São Paulo: Instituto Alana, 2009. p. 111-121.

ELLER, J. D. Introdução à antropologia da religião. Petrópolis: Vozes, 2018.

FREITAS, L. C de. A reforma empresarial da educação: nova direita, velhas ideias. São Paulo: Expressão Popular, 2018.

GIBRAN, K. G. O profeta. Rio de Janeiro: Record, 1981.

KARNAL, L. et al. História dos Estados Unidos: das origens ao século XXI. São Paulo: Contexto, 2007.

LABRIOLLE, P. et al. Los reinos germánicos. Valencia: EDICEP, 1975. (Colección Historia de la iglesia: de los orígenes a nuestros días - dirigida por Agustin Fliche y Victor Martin, 4).

LACÉ, A. M.; SANTOS, C. de A.; NOGUEIRA, D. X. P. Entre a escola e o quartel: a negação do direito à educação. Revista Brasileira de Política e Administração da Educação [online], v. 35, n. 3, p. 648 - 666, set./dez. 2019. DOI: https://doi.org/10.21573/vol35n32019.96856

LACERDA, M. B. O novo conservadorismo brasileiro: de Reagan a Bolsonaro. Porto Alegre: Zouk, 2019.

LIMA, I. G..; HYPOLITO, A. M. A expansão do neoconservadorismo na educação brasileira. Educação e Pesquisa, São Paulo, v. 45, p. 1-15, ago. 2019. DOI: https://doi.org/10.1590/s1678$\underline{463420194519091}$

MARTINS, A. A. Sobre os dias atuais: neoconservadorismo, escolas cívico-militares e o simulacro da gestão democrática. Revista Brasileira de Política e Administração da Educação [online], v. 35, n. 3, p. 689-699, set./dez. 2019. DOI: https://doi.org/10.21573/vol35n32019.94577 
MIGUEL, L. F. Da "doutrinação marxista” à "ideologia de gênero": Escola sem Partido e as leis da mordaça no parlamento brasileiro. Revista Direito \& Práxis, Rio de Janeiro, v. 7, n. 15, p. 590621, 2016. DOI: https://doi.org/10.12957/dep.2016.25163

MILOT, M. La laicidad. Madrid: Editorial CCS, 2009.

MOLL, R. Reaganetion: a nação e o nacionalismo (neo) conservador nos Estados Unidos (19811988). 2010. 265 f. Dissertação (Mestrado em História) - Universidade Federal Fluminense, Niterói, 2010.

MONOD, J. C. Qué es la laicidad. Barcelona: Editorial Proteus, 2013.

PANASIEWICZ, R. Fundamentalismo religioso: história e presença no cristianismo. 2008. Disponível em: <http://www.abhr.org.br/wp-content/uploads/2008/12/panasiewiczroberlei.pdf>. Acesso em: 30 dez. 2019.

PENNA, F. de A. O discurso reacionário de defesa do projeto "Escola sem Partido". Revista Quaestio, Sorocaba, v. 20, n. 3, p. 567-581, dez. 2018. DOI: https://doi.org/10.22483/2177$\underline{5796.2018 v 20 n 3 p 567-581}$

PENNA, F. de A. A defesa da "educação domiciliar" através do ataque à educação democrática: a especificidade da escola como espaço de dissenso. Linguagens, Educação e Sociedade, Teresina, n. 42, p. 8-28, maio/ago. 2019. DOI: https://doi.org/10.26694/les.v0i42.9336

PICHONELLI, M. Homeschooling e a domesticação do aluno. In: CÁSSIO, F. (org.). Educação contra a barbárie: por escolas democráticas e pela liberdade de ensinar. São Paulo: Boitempo, 2019, p. 99-105.

SANTIN, M. A. V.; CATTANI, D.; CECCHETTI, E. Gênero e religião: disputas políticas na construção do plano municipal de educação de Chapecó/SC. Revista Pedagógica, Chapecó, v. 21, p. 306-320, 2019.

SILVEIRA, A. A. D. Atuação do Ministério Público para a proteção do direito à educação básica. In: RANIERI, N. B. S. (Coord.); RIGHETTI, S. (Org.). Direito à educação: aspectos constitucionais. São Paulo: Editora da Universidade de São Paulo, 2009. p. 123-141.

SOUZA, A. S. de. Religião e educação: as marcas do fundamentalismo religioso no programa "Escola sem Partido". Revista Religare, João Pessoa, v. 16, n. 1, p. 9-33, ago./2019.

VASCONCELOS, M. C. C.; BOTO, C. A educação domiciliar como alternativa a ser interrogada: problema e propostas. Práxis Educativa, Ponta Grossa, v. 15, e2014654, p. 1-21, 2020. DOI: https://doi.org/10.5212/praxeduc.v.15.14654.019 